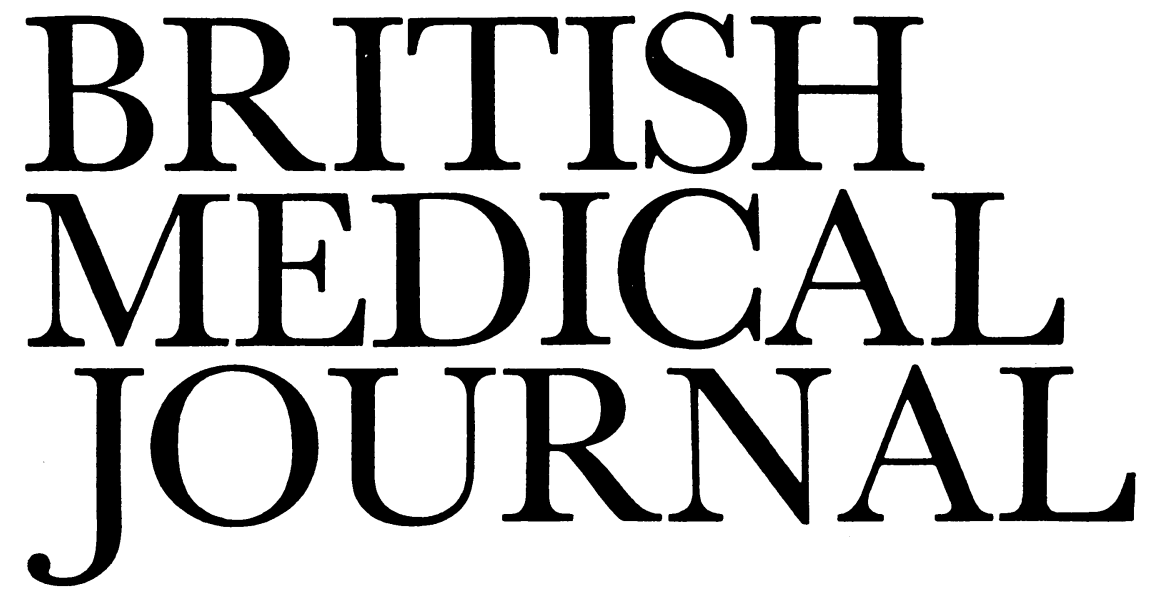

LONDON, SATURDAY 15 MARCH 1986

\title{
Risk of AIDS to health care workers
}

No health care worker in the world has contracted the acquired immune deficiency syndrome (AIDS) from a patient. Seroconversion to human $\mathrm{T}$ cell lymphotropic virus type III (HTLV-III) has, however, occurred. A nurse in England sustained a needlestick injury while resheathing a hypodermic needle on a syringe containing fresh blood drawn from an arterial line in a patient suffering from AIDS acquired in Africa.' Two weeks later she developed a transient "flu-like" illness associated with rash and lymphadenopathy, and her blood became positive for HTLV-III. Eighteen months later she remained well. Since that accident 89 hospital staff in England and Wales who had been accidentally exposed to the blood or body fluids of patients infected with HTLV-III have been studied prospectively. ${ }^{2}$ Forty three were nurses, doctors, or laboratory staff who had sustained needlestick or other sharp injuries. All 89 have been followed up for periods of one to 11 months (median four months). None have developed serum antibodies to HTLV-III.

The Weekly Epidemiological Record of the World Health Organisation (18 October 1985) described the results of a serological study of 1758 health care staff in the United States who had directly (nurses and doctors) or indirectly (laboratory staff) been in contact with patients suffering from AIDS and related disorders. Twenty six $(1 \cdot 5 \%)$ were found to have HTLV-III antibody in their blood but 23 of these were in a recognised high risk group (homosexual men). Of the remaining three, no information was available on one; the other two had sustained needlestick injuries with blood known to be infected with HTLV-III, though one of the accepted routes of transmission of infection could not definitely be excluded. ${ }^{3}$

J L Gerberding et al have reported the results of a prospective study of 160 hospital staff, including nurses, clinicians, and laboratory workers, who have been concerned since 1981 in the care of 500 patients suffering from AIDS at San Francisco General Hospital (paper to 1985 Interscience Congress on Antimicrobial Agents and Chemotherapy). One third of the 160 had sustained a needlestick injury or contamination of the skin with blood infected with HTLVIII, but none showed seroconversion. Shanson and his colleagues at St Stephen's Hospital in London have carried out serological studies on 150 hospital staff who have cared for 400 patients infected with HTLV-III (including 80 who have undergone surgery or other invasive procedures). ${ }^{4}$ Not one of the 150 has shown evidence of infection with the virus.

Friedland $e t$ al studied prospectively the risk of household transmission of HTLV-III to siblings, children, and parents of 39 adults suffering from AIDS. ${ }^{5}$ The median duration of home contact with patients with symptoms to time of screening was 22 months. One hundred and one non-sexual contacts of patients with AIDS who were living in the same home as the patient and sharing all household facilities were included in the study. Only one of the 101 contacts had evidence of infection with the virus-a 5 year old girl who had almost certainly contracted the infection perinatally from her mother, who was an intravenous drug abuser suffering from AIDS. This reassuring study suggests that transfer of HTLV-III does not occur by casual contact, including kissing. Although the virus can be cultured from saliva the amounts are small and possibly not infectious. ${ }^{67}$

The risk factors which might lead to health service staff contracting infection with HTLV-III from a patient are similar to those associated with hepatitis $B$ virus infection. HTLV-III seems, however, to be less communicable than the hepatitis B virus: health service staff contaminated by blood infected with both viruses have contracted hepatitis B but not HTLV-III infection. ${ }^{8}$ Possibly the infectious dose of HTLV-III is greater than that of the hepatitis B virus, and as many as $10^{13}$ hepatitis $B$ viral particles are present in $1 \mathrm{ml}$ of infected blood compared with only $10^{4}$ for HTLV-III. ${ }^{9}$

When a patient who is known to be positive for HTLV-III is admitted to hospital the laboratory must be informed by the ward sister, and all specimens from the patient should be labelled with a biohazard sticker similar to that used for hepatitis B. Both clinicians and laboratory staff must ensure that every effort is made to maintain confidentiality (as already happens with specimens submitted for the diagnosis of other sexually transmitted diseases). Lists of HTLV-III positive patients should not be displayed prominently in wards or laboratories. Dedicated laboratory equipment is not necessary for routine specimens in these patients. Specimens should be handled and processed in the same way as those from patients with hepatitis B surface antigen ( $\mathrm{HBsAg}$ ). Gloves must be worn. Serum and plasma should be centrifuged in sealed cups. Work surfaces must be disinfected after 
use and after blood spillage with sodium hypochlorite $(10000$ ppm available chlorine). Exposure to $2 \%$ glutaraldehyde for at least 30 minutes, or autoclaving, will inactivate HTLV-III on equipment, which should first be washed to remove particulate matter.

The clinical care of patients infected with HTLV-III is also similar to that recommended for those who are HBsAg positive. Staff should wear gloves and a plastic apron when attending to the patient. Eye protection is recommended during surgery and other invasive procedures. Instructions must be readily available to guide staff in the event of blood spillage. Single room isolation is not generally necessary unless HTLV-III positive patients are bleeding, incontinent, psychotic, dying, or suffering from another communicable disease such as tuberculosis or a salmonella infection. It seems unwise, however, to nurse patients with HTLV-III in the same ward as patients who are immunocompromised for other reasons. Usually these wards are very busy and invasive procedures are being carried out frequently; there is therefore the risk of two way transmission of infection.

A comprehensive review of AIDS and related disorders including the recommendations of the Hospital Infection
Society Working Party on AIDS has been published recently as a supplement to the Fournal of Hospital Infection. ${ }^{10}$

Alasdair M GeDdes

Professor of Infectious Diseases,

University of Birmingham,

East Birmingham Hospital,

Birmingham B9 5ST

1 Anonymous. Needlestick transmission of HTLV3 from a patient infected in Africa [Editorial] Lancet 1984;ii: 1376-7.

2 Communicable Disease Surveillance Centre. Communicable Disease Report. Weekly. 1985 Dec 27 $(85 / 52$.

3 Sande MA. Transmission of AIDS. The case against casual contagion. $N$ Engl 7 Med 1986;314:380-2.

4 Shanson DC, Evans R, Lai L. Incidence and risk of transmission of HTLV3 infection to staff at a London hospital 1982-85. I Hosp Infect 1985; 6(suppl C): 15-22.

5 Friedland GH, Saltzman BR, Rogers MF, et al. Lack of transmission of HTLV-III/LAV infection to household contacts of patients with AIDS or AIDS-related complex with oral candidiasis. $N$ Engl f Med 1986;314: 344-9.

6 Ho DD, Byington RE, Schooley RT, Flyn T, Rota TR, Hirsch MS. Infrequency of isolation of HTLV3 virus from saliva in AIDS. $N$ Engl f Med 1985;313:1606.

7 Schechter MT, Boyko WJ, Douglas B, et al. Can HTLV3 be transmitted orally? Lance 1986; $: 379$.

8 Gerberding JL, Hopewell PC, Kaminsky LS, Sande MA. Transmission of hepatitis B without transmission of AIDS by accidental needlestick. $N$ Engl F Med 1985;312:56.

9 Levy JA Kaminsky IS Marrow JW, et al. Infection by the retrovirus associated with the acquired immune deficiency syndrome. Ann Interm Med 1985;103:694-9.

10 Shanson DC, Sanderson PJ, eds. Proceedings of a Hospital Infection Society symposium on the acquired immune deficiency syndrome. I Hosp Infect 1985;6(suppl C): 1-80.

\section{Government hypocrisy on drugs}

Why has the government got so excited about illicit drug abuse but been so consistently low key in its response to the damage to health caused by smoking and alcohol abuse? This question will be raised next week at an international conference in London of ministers of health which is to look at misuse of narcotic and psychotropic drugs. The British government will boast that it has given about $£ 22 \mathrm{~m}$ for responding to illicit drug abuse in Britain since 1984-but it will probably not mention that it found last year less than $£ 4 \mathrm{~m}$ and $£ 1 \mathrm{~m}$ respectively for preventing the harm caused by smoking and alcohol. Nor will it want attention drawn to its chicken feed annual grant of $£ 150000$ to Action on Smoking and Health or its refusal to give any money at all to Action on Alcohol Abuse, despite a government sponsored report advocating its creation.

The government must be acting this way, an innocent bystander might assume, because illicit drug abuse is a much more serious problem than tobacco or alcohol abuse. Illicit drug abuse is rightly causing great concern, and in 1984, the Home Office says, it led to 235 deaths. Yet in the same year about 100000 people died prematurely through smoking and probably over 25000 through alcohol abuse. Certainly many of the deaths related to illicit drug abuse occurred in young people, but so did many of those that were alcohol related: alcohol intoxication plays a part in the deaths of 500 people under 25 each year. Furthermore, in two thirds of the deaths related to illicit drugs the Home Office says that alcohol was a contributory factor.

Might it be then, our innocent bystander asks, that illicit drug abuse causes more morbidity than either tobacco or alcohol abuse? Illicit drug use is certainly associated with a wide range of physical, psychological, and social problems, but the extent of these is hard to quantify. Tobacco causes few psychological or social problems but leads to an enormous amount of physical disability and costs the country very dear in treatment and days lost from work. Alcohol, by contrast, is associated with a bewilderingly wide range of physical, psychological, and social problems, and a conservative estimate says that alcohol abuse costs Britain $£ 1 \cdot 6$ billion every year.

Perhaps, then, our intelligent and innocent bystander suggests, so much more is spent on preventing drug abuse because such campaigns are more cost effective than those designed to prevent tobacco or alcohol abuse. But the government's mass media campaign to prevent illicit drug use (which must have swallowed much of the money because using the media is expensive) has been roundly condemned by drug experts, who quote detailed evaluations showing that such campaigns are at best a waste of time and at worst actually increase drug abuse. Nor has the fimsy market research produced by the government done anything to answer these criticisms. For it is much more difficult to control an illegal than a legal activity, and the government's campaign is being undone both by market forces operating among Middle and Far Eastern poppy farmers and by the despair spreading among the young in Britain's inner cities.

Yet while it fights an expensive and losing battle against illicit drug abuse the government is allowing hundreds of millions of pounds to be spent promoting tobacco and alcohol. Now our innocent bystander is becoming very confused. How can it be that the government spends so much money trying to stamp out the use of drugs that kill hundreds when it allows the promotion of drugs that kill tens of thousands? There is no dispute that if it wanted the government could do much to reduce the use of tobacco and alcohol by banning promotion, increasing costs, and reducing availability. The answer must be that it has a vested interest in the widespread consumption of these products, raising many millions of pounds through tax on them. It is ironic, too, that while prison sentences are being increased for the pushers of illegal drugs a takeover battle involving billions of pounds is being fought for the privilege to push alcohol and tobacco.

In the shires of England, where the present government 